\title{
TERRITORIAL ORGANIZATION OF HEALTHCARE IN RIVNE REGION IN THE FOCUS OF HUMAN GEOGRAPHY
}

\author{
Anastasia HREBEN \\ Nizhyn Gogol State University, Ukraine \\ serg1234serg@meta.ua
}

\begin{abstract}
The feasibility of in-depth analysis of the territorial organization of the healthcare system in Rivne region is determined primarily by the need to assess the quality of public health facilities operation and their availability in the region, which suffered significant radioactive contamination as a result of the Chernobyl accident.

The main goal of this study was to determine the characteristics of the territorial organization of healthcare system in Rivne Region assessing its impact on the medical and demographic situation in the region. Analysis of the territorial organization of medical services in Rivne Region was carried out by determining the number of parameters (localization index, index of territorial concentration, service area, and service radius).

The best indicators of the ratio of health care institutions to the population are observed in Ostroh, Rivne, Kostopil and Zdolbunov districts. The biggest discrepancy between these figures were found in Berezne, Koretsk, Volodymyrets and Dubrovytsya districts, primarily due to the peripheral location of these districts in the region. Similar differences have developed well in terms of access to medical facilities.

The smallest service areas of medical institutions are (188-244 sq. km) in Demydiv, Zdolbuniv, and Berezne districts. The biggest service areas of medical institutions are in Dubno, Kostopil, Ostroh, and Goshcha districts (692-1200 sq km).

In general, the southern and central parts of the region are better provided with medical facilities. Rivne district should be noted separately for the best indicators of public healthcare due to its "capital" status.

A correlation analysis was conducted in order to establish the relationship between the number of hospitals, on the one hand, and medical and demographic indicators (total mortality, morbidity, and spread of diseases). The results indicate a strong dependence: $r 1=0.7, r 2=0.8, r 3=0.9$ respectively. This means that the public health depends significantly on the level of medical care.
\end{abstract}

Key words: healthcare system, territorial organization, service radius, territorial accessibility, health, Rivne Region.

DOI: http://dx.doi.org/10.17721/2413-7154/2016.75.63-68

UDC: $911.3 .30(477.81)$

\section{СУСПІЛЬНО-ГЕОГРАФІЧНІ ОСОБЛИВОСТІ ТЕРИТОРІАЛЬНОӦ ОРГАНІЗАЦІї СИСТЕМИ ОХОРОНИ ЗДОРОВ'Я РІВНЕНСЬКОЇ ОБЛАСТІ}

\author{
Анастасія ГРЕБЕНЬ \\ Ніжинський державний університет імені Миколи Гоголя, Україна \\ serg1234serg@meta.ua
}

Анотація: Доцільність поглибленого аналізу територіальної організації системи охорони здоров'я Рівненської області визначається перш за все необхідністю проведення оцінки якості функціонування та доступності для населення медичних установ у регіоні, який зазнав значного радіоактивного забруднення у результаті аварії на Чорнобильській AEC.

Головною метою даного дослідження $\epsilon$ визначення особливостей територіальної організації системи медичного обслуговування населення Рівненської області у контексті оцінки її впливу на медико-демографічну ситуацію у регіоні. Аналіз територіальної організації системи медичного обслуговування населення Рівненської області здійснювався шляхом визначення низки показників (індекс локалізації, індекс територіальної концентрації, зона обслуговування, радіус обслуговування).

Відповідно до проведених обчислень, оптимальні показники співвідношення кількості медичних закладів та населення спостерігаються в Острозькому, Рівненському, Костопільському та Здолбунівському районах. Найбільша невідповідність між даними показниками у Березнівському, Корецькому, Володимирецькому та Дубровицькому районах, що пов'язано в першу чергу з периферійним розташуванням цих районів в області. Аналогічні відмінності склалися також і за показниками доступності медичних установ. У Демидівському, Здолбунівському та Березнівському районах зона обслуговування одного лікарняного закладу $\epsilon$ найменшою - 188-244 км2, у Дубенському, Костопільському, Острозькому та Гощанському, навпаки, найбільшою - 692-1200 км2. Загалом південні та центральні райони області краще забезпечені медичними закладами. Окремо слід відзначити Рівненський район, де найкращі показники забезпеченості населення лікувальними установами визначаються його "столичним" статусом.

3 метою встановлення взаємозв'язку між кількістю лікувальних установ та медико-демографічними показниками (загальна смертність, рівень захворюваності та поширення хвороб) було проведено кореляційний аналіз. Його результати свідчать про наявність сильної залежності - r1=0,7, r2=0,8, r3=0,9 відповідно. Це свідчить про те, що стан здоров'я населення суттєво залежить від рівня розвитку медичного обслуговування.

Ключові слова: система медичного обслуговування, територіальна організація, радіус обслуговування, територіальна доступність, здоров'я населення, Рівненська область.

DOI: http://dx.doi.org/10.17721/2413-7154/2016.76.63-68

Удк: 911.3 .30 (477.81) 
Вступ. Постановка проблеми. Одним iз основних наслідків трансформації соціальної сфери України має стати ефективне функціонування системи охорони здоров'я, результати діяльності якої значною мірою визначають соціально-економічні показники розвитку суспільства.

Несприятлива медико-демографічна ситуація в Україні в цілому та в окремих її регіонах вимагає термінового впровадження заходів щодо поліпшення соціально-економічного становища громадян, оптимізації фінансування системи охорони здоров'я 3 метою підвищення якості надання лікувальнопрофілактичної допомоги та забезпечення доступності медичних послуг для соціально незахищених верств населення. У зв'язку 3 цим надзвичайної актуальності набуває проблема удосконалення як просторової організації, так i загального функціонування системи охорони здоров’я, у першу чергу, на регіональному рівні.

Доцільність поглибленого аналізу територіальної організації системи охорони здоров'я Рівненської області визначається перш за все необхідністю проведення оцінки якості функціонування та доступності для населення медичних установ у регіоні, який зазнав значного радіоактивного забруднення у результаті аварії на Чорнобильській AEC.

Аналіз останніх досліджень і публікацій. Вивченням питань здоров'я населення займалися i займаються передусім вчені-медики, яким належать численні дослідження та наукові розробки. Питання організації охорони здоров'я вивчали О. Возіанов, В. Москаленко, С. Подолинський, В. Рудень, В. Сміянов та інші.

Дослідження теоретичних основ статистики охорони здоров'я i наукове обгрунтування ролі держави у фінансовому забезпеченні цієї галузі здійснювали представники різних наукових шкіл, зокрема: П. Самуельсон, Г. Беккер, Дж. Кендрік. Серед українських науковців, які вивчали економічні закономірності функціонування медичного обслуговування i досліджували практику організації системи охорони здоров'я, можна назвати А. Голяченка, М. Шутова, Ю. Вороненка.

Актуальними $€$ також розробки питань державного управління в галузі охорони здоров'я (3. Гладун, В. Лехан), соціально-економічні та регіональні аспекти сфери охорони здоров'я (В. Куценко, Г. Трілленберг).

Вивченням геопросторової організації та функціонування системи охорони здоров'я займаються також представники географічної науки. Теоретичні та прикладні проблеми геопросторової організації медичного обслуговування досліджували В. Барановський, М. Білецький, I. Дудник, В. Джаман, О. Заставецька, О. Топчієв, О. Шаблій, Л. Шевчук, В. Шевченко. Медико-географічні дослідження проводилися Г. Барковою, С. Куролапом, С. Рященко, А. Келлером, О. Шошиним.

Суспільно-географічні дослідження

сфери

(C) А. Гребень охорони здоров’я в Україні є малочисельними, хоча в окремих роботах вказується на існуючу залежність між показниками захворюваності населення певних територій і рівнем надання медичних послуг. Як приклад, можна навести роботи Д. Арзянцева, Г. Баркової,В.Гуцуляка,Н.Корнілової,І.Манаєнкової, I. Мартусенко, Н. Мезенцевої, Подвірної, О. Романів, Д. Шиян та інших дослідників.

Вагомий внесок у розвиток медичного картографування зробили В. Барановський, В. Гуцуляк, Я. Жупанський, К. Пироженко, В. Шевченко та інші. В. Кубійович у «Атласі України і суміжних країн» (Львів, 1937) навів карти загальної смертності населення, зокрема смертності дітей, що $\epsilon$ зразком першого вітчизняного медикогеографічного картографування.

Формулювання цілей статті. Постановка завдання. Головною метою даного дослідження $є$ визначення особливостей територіальної організації системи медичного обслуговування населення Рівненської області у контексті оцінки їі впливу на медико-демографічну ситуацію у регіоні. 3 урахуванням мети роботи були сформульовані такі дослідницькі питання: 1) які просторові особливості розміщення медичних установ сформувалися у Рівненській області?; 2) наскільки значними є міжрайонні відмінності у показниках доступності медичних закладів для населення?; 3) чи дійсно рівень забезпеченості населення медичними закладами та їх доступність для жителів області впливають на медико-демографічну ситуацію у цьому регіоні?

Методичні аспекти дослідження. Першоосновою наукового аналізу територіальної організації системи медичного обслуговування населення $€$ формування відповідної статистичної бази та системи показників. Інформаційну основу дослідження склали матеріали головного управління статистики Рівненської області та управління охорони здоров'я Рівненської обласної державної адміністрації. Аналіз територіальної організації системи медичного обслуговування населення Рівненської області здійснювався шляхом визначен-ня низки показників, які характеризують особливості просторової концентрації та локалізації медичних установ у розрізі районів цього регіону. Поряд із статистичним, у дослідженні використовувалися також картографічний метод (для візуалізації розміщення медичних закладів) i кореляційний аналіз (для оцінки впливу системи медичного обслуговування на стан медикодемографічної ситуації).

Виклад основного матеріалу.

За визначенням ВОО3, сучасна система охорони здоров'я повинна забезпечувати доступність медичних послуг для тих, хто їх найбільше потребує, характеризуватися високою якістю й безпечністю медичних послуг та забезпечувати максимально можливі результати для здоров’я на популяційному рівні [3, с. 5].

Система медичного обслуговування Рівненської області у 2014 році була представлена 52 лікарнями 
та 257 лікарськими амбулаторно-поліклінічними закладами. Забезпеченість населення лікарями усіх спеціальностей складала 41,1 лікарів у розрахунку на 10000 населення. Це дещо нижче за пересічний для України показник, який становить 43,5 лікарів. У медичних установах Рівненької області налічується 9513 лікарняних ліжко-місць, що у розрахунку на 10000 населення становить 82 одиниці (пересічний для країни показник - 78,5 од.).

Рівень і необхідність у користуванні послугами медичних закладів відображає кількість відвідувань за зміну амбулаторно-поліклінічних закладів. Для Рівненської області цей показник у 2014 році становив 245,4 звернень (у розрахунку на 10000 осіб) і був дещо вищим за аналогічний показник для країни 213,4 звернень [4,5].

Поруч 3 аналізом кількісних показників діяльності системи охорони здоров'я, важливим $\epsilon$ дослідження іiї територіальної організації, оскільки всі заклади охорони здоров'я неоднаково розміщені по території, функціонують під впливом різних чинників, що сукупно визначає особливості надання медичних послуг у різних регіонах країни.

Особливості просторової організації системи охорони здоров'я Рівненської області можна проаналізувати за допомогою індексів. Для дослідження розвитку системи охорони здоров'я використовувалися індексів локалізації ( $\left.\mathrm{I}_{\text {лк }}\right)$ та територіальної концентрації ( $\mathrm{I}_{\text {тк }}$ ) медичних установ у розрізі її адміністративних районів.

Індекс локалізації визначається за формулою: Iлк $=\left(\mathrm{p}^{*} \mathrm{~N}\right) /(\mathrm{P} * \mathrm{n})$ [2], де $\mathrm{I}_{\text {лк }}$ - індекс локалізації, $\mathrm{p}-$ кількість медичних закладів у районі; $\mathrm{P}$ - кількість медичних закладів в області; $\mathrm{N}$ - кількість населення в області; $\mathrm{n}$ - кількість населення в районі.

Якщо $\mathrm{I}_{\text {лк }} \in$ близьким до 1, то система охорони здоров’я розвинена пропорційно до частки населення певного району у загальній чисельності населення області. Відповідно до проведених обчислень, оптимальні показники індекса локалізації спостерігаються в Острозькому, Рівненському, Костопільському та Здолбунівському районах (табл. 1). Найбільша невідповідність між кількістю медичних закладів та кількістю населення у Березнівському, Корецькому, Володимирецькому та Дубровицькому районах, що пов'язано в першу чергу з периферійним розташуванням цих районів в області.

Індекс територіальної концентрації $\left(\mathrm{I}_{\text {тк }}\right)$ дає можливість визначити зосередженість медичних закладів на певній території відносно пересічного для області рівня. Він визначається за формулою: $\mathrm{I}_{\text {тк }}=(\mathrm{p} * \mathrm{~S}) /(\mathrm{P} * \mathrm{~s})$ [2], де $\mathrm{I}_{\text {тк }}-$ індекс територіальної концентрації, p - кількість медичних закладів у районі; Р - кількість медичних закладів в області в цілому; s - площа території району; $\mathrm{S}$ - площа території області.

Його значення менше за 1 свідчить про низьку концентрацію медичних закладів у певному адміністративному районі, вище за 1, навпаки, - про високу щільність медичних установ.

Отже, найбільше закладів, що надають медичну допомогу на одиницю площі, спостерігається у Демидівському, Здолбунівському, Корецькому та Березнівському районах. Найменша щільність медичних закладів у Костопільському, Гощанському, Дубенському та Острозькому районах (табл. 1).

Аналіз кількісного складу медичних установ у розрізі адміністративних районів не дає повноцінної картини доступності закладів охорони здоров'я для населення у межах регіону. Важливим у цьому плані є дослідження територіальної доступності лікарняних закладів. Для оцінки останньої доцільно проаналізувати показники зони та радіусу

Індекси локалізації та територіальної концентрації закладів охорони здоров’я

Таблиия 1. у розрізі районів Рівненської області

\begin{tabular}{|c|c|c|c|c|c|}
\hline Райони & 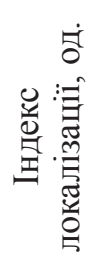 & 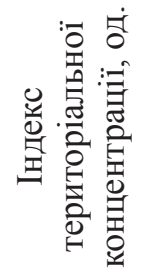 & Райони & 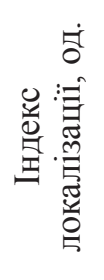 & 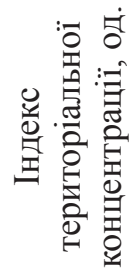 \\
\hline Березнівський & 2,73 & 1,74 & Корецький & 2,17 & 1,78 \\
\hline Володимирецький & 1,58 & 0,88 & Костопільський & 0,76 & 0,57 \\
\hline Гощанський & 0,69 & 0,62 & Млинівський & 1,29 & 0,9 \\
\hline Демидівський & 3,36 & 2,26 & Острозький & 0,85 & 0,62 \\
\hline Дубенський & 0,54 & 0,36 & Радивилівський & 1,32 & 1,15 \\
\hline Дубровицький & 1,54 & 0,7 & Рівненський & 0,83 & 1,09 \\
\hline Зарічненський & 2,12 & 0,89 & Рокитнівський & 1,82 & 0,73 \\
\hline Здолбунівський & 1,3 & 1,94 & Сарненський & 1,46 & 1,3 \\
\hline
\end{tabular}

Розраховано автором [5] 
обслуговування медичних установ області. Формули їхніх обчислень подібні між собою: $\mathrm{T}=\mathrm{S} / \mathrm{n} ; \mathrm{R}=\sqrt{\mathrm{S}} / \mathrm{n}$ [1, с. 126], де $\mathrm{T}$ - зона обслуговування; $\mathrm{R}$ - радіус обслуговування; $\mathrm{S}$ - площа адміністративного району; n - кількість медичних закладів у адміністративному районі.

За результатами обчислень були виявлені значні міжрайонні відмінності у територіальній доступності закладів охорони здоров'я для населення Рівненської області (табл. 2).

Найменша зона обслуговування медичних закладів у Демидівському, Здолбунівському та Березнівському районах. Це свідчить про те, що ці райони відносно краще забезпечені медичними закладами. Радіус обслуговування однієї медичної установи у цих районах також найменший, що дає підставити стверджувати про вищий рівень доступності для населення медичних установ. Серед обставин, які можуть погіршувати доступність медичних послуг, слід виокремити якість доріг, конфігурацію транспортної мережі, технічний стан карет швидкої допомоги тощо.

Найбільші зони обслуговування закладів охорони здоров'я у Дубенському, Костопільському, Острозькому та Гощанському районах зумовили, відповідно, і значні радіуси надання послуг одним медичним закладом. Така ситуація $\epsilon$ досить небезпечною, коли йдеться про збереження здоров'я населення, особливо у випадках травм, гострих захворювань, отруєннях чи пологах, коли необхідно швидко надати медичну допомогу або використати спеціальне обладнання. Географічне розташування закладів не завжди відповідає особливостям розселення населення, частина якого має долати значні відстані для отримання лікарської допомоги. Тому проблема територіальної доступності медичних закладів у цих районах потребує першочергового вирішення.

Загалом південні та центральні райони області краще забезпечені медичними закладами. Зокрема, на тлі інших чітко виділяється Рівненський район, що пояснюється значною кількістю лікувальних закладів, які розміщуються в обласному центрі. Також досить густа мережа закладів охорони здоров'я у Корецькому та Радивилівському районах.

Існуюча система надання медичної допомоги, особливо сільському населенню, недостатньо ефективна. Лікувально-профілактичні заклади мало відповідають потребам пацієнтів, відтак нагальною є потреба удосконалення функціональноорганізаційної моделі системи охорони здоров'я області на засадах сімейної медицини та їі просторової організації. У північних (Зарічненському, Дубровицькому та Рокитнівському) районах невирішеним залишається питання приведення до відповідності кількості медичних установ i кількості населення. Воно потребує першочергового розв'язання.

Просторові особливості системи медичного обслуговування населення Рівненської області відображені на рис. 1. Очевидно, що більш густа мережа лікувальних установ спостерігається у південних районах області. Проведені розрахунки відношення кількості медичних закладів до

Таблиия 2.

Територіальна доступність закладів охорони здоров’я

\begin{tabular}{|c|c|c|c|c|c|}
\hline Район & 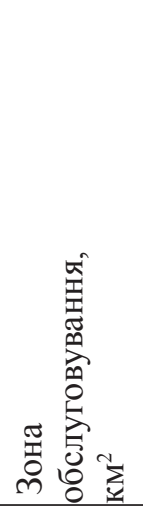 & 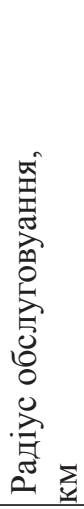 & Район & 告 & 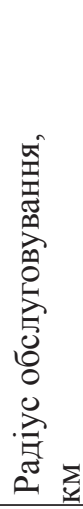 \\
\hline Березнівський & 244 & 15,6 & Корецький & 240 & 15,5 \\
\hline Володимирецький & 485 & 22,0 & Костопільський & 748 & 27,3 \\
\hline Гощанський & 692 & 26,3 & Млинівський & 472 & 21,7 \\
\hline Демидівський & 188 & 13,7 & Острозький & 693 & 26,3 \\
\hline Дубенський & 1200 & 34,6 & Радивилівський & 372 & 19,3 \\
\hline Дубровицький & 606 & 24,6 & Рівненський & 392 & 19,8 \\
\hline Зарічненський & 480 & 21,9 & Рокитнівський & 587 & 24,2 \\
\hline Здолбунівський & 219 & 14,8 & Сарненський & 328 & 18,1 \\
\hline
\end{tabular}

Розраховано автором $[4,5]$ 


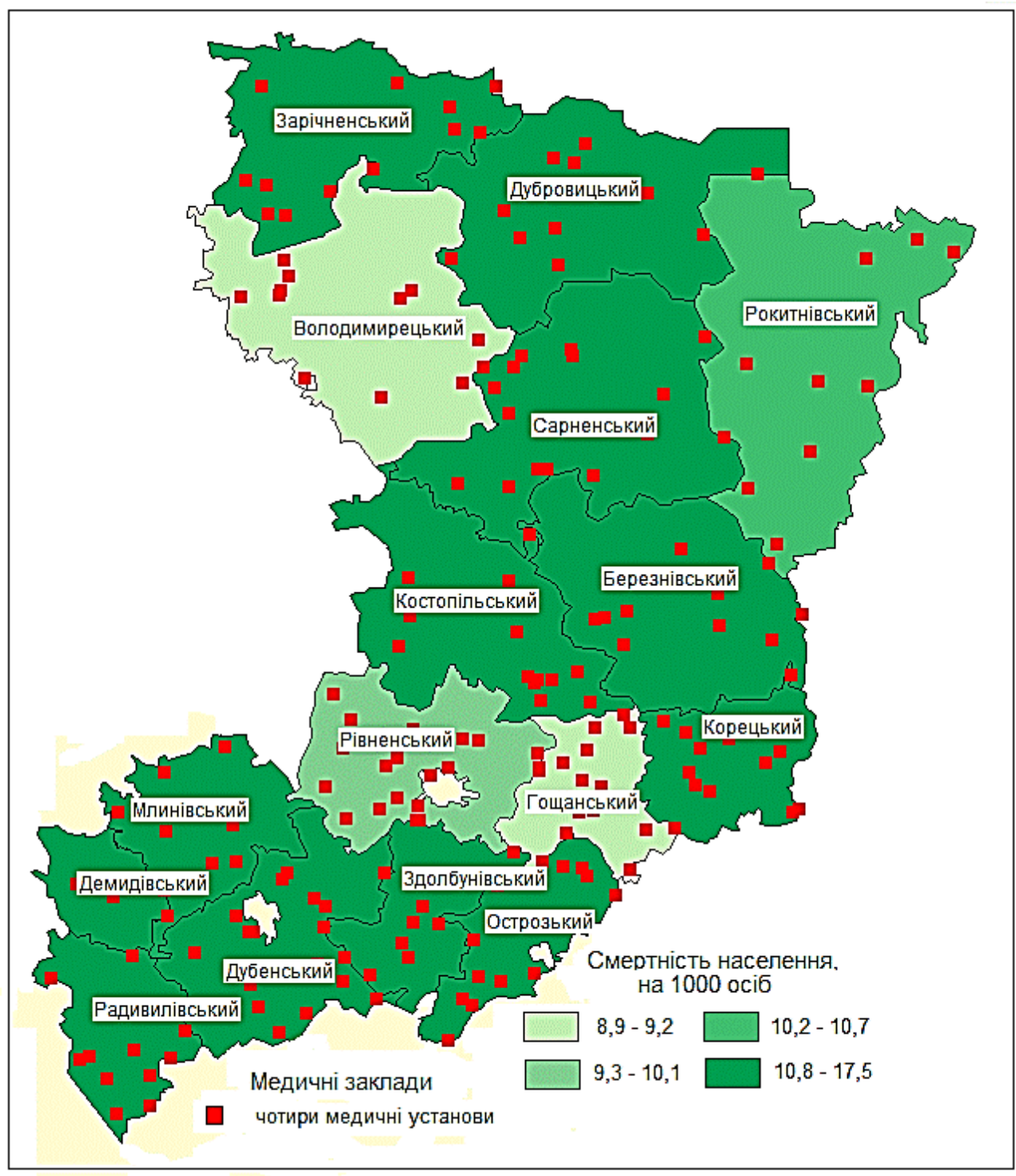

Рис. 1. Територіальна організація закладів охорони здоров'я (побудовано автором $[4,5]$ ).

територіальної доступності лікувальних закладів дають змогу стверджувати, що саме Здолбунівський район найбільш оптимально забезпечений закладами охорони здоров'я. Що стосується інших південних районів, то ситуація неоднозначна: Острозький район характеризується пропорційною кількістю медичних установ та населення, однак наявна проблема територіальної доступності, яка $\epsilon$ також актуальною і для Дубенського та Гощанського районів. Демидівський та Корецький райони характеризуються високою щільністю медичних закладів і зручною їх доступністю, але це за рахунок ФАПів та амбулаторій; лікувальні заклади, що надають більш спеціалізовану медичну допомогу розташовані у сусідніх районах.

Кількість лікувальних установ у північних районах, зокрема у Володимирецькому та Дубровицькому, не відповідає кількості населення. Також радіуси обслуговування лікувальних закладів одні 3 найбільших в області саме у північних районах. Однак на цьому тлі вирізняється Березнівський район, який характеризується зручною доступністю медичних установ.
Побутує думка, що демографічні показники, насамперед показники смертності населення, а також захворюваність громадян, залежать від рівня розвитку і просторової організації системи медичного обслуговування.

3 метою встановлення взаємозв'язку між зазначеними показниками, було проведено кореляційний аналіз. Його результати свідчать про наявність сильної залежності між показниками забезпеченості населення закладами охорони здоров'я й окремими медичними та демографічними характеристиками (табл. 3). Зокрема, найбільша залежність простежується між кількістю лікувальних закладів та рівнем захворюваності (в деяких адміністративних районах $\mathrm{r}=0,985)$. Також високі показники залежності простежуються між кількістю закладів охорони здоров'я та поширенням хвороб (максимальне значення $\mathrm{r}=0,988$ у Радивилівському районі). Це свідчить про те, що стан здоров'я населення суттєво залежить від рівня розвитку медичного обслуговування.

Отже, беручи до уваги місцеві проблеми функціонування мережі лікувальних закладів, 
Таблиця 3.

Результати кореляційного аналізу

\begin{tabular}{|l|c|}
\hline & Кількість закладів охорони здоров'я \\
\hline Поширення хвороб & 0,831 \\
\hline Загальна смертність & 0,708 \\
\hline Рівень захворюваності & 0,839 \\
\hline
\end{tabular}

Розраховано автором [5]

ефективна стратегія розвитку регіональної системи охорони здоров'я має враховувати територіальні особливості медико-демографічної ситуації, забезпечувати попередження структурних та просторових деформацій, підвищення доступності та якості медичного обслуговування населення.

Важливу роль у формуванні дієвої мережі закладів медичного обслуговування відіграє відкриття спеціалізованих лікувальних установ у компетенції яких буде профілактика та лікування нозологій, які $\epsilon$ індикаторними для території Рівненщини (онкологічні захворювання, новоутворення, захворювання ендокринної системи, крові, патології вагітності тощо).

\section{Висновки. Перспективи}

подальших досліджень. Проведений аналіз територіальної організації системи медичного обслуговування населення Рівненської області дав змогу сформулювати наступні висновки.

1. Територіальна система медичного обслуговування населення Рівненської області характеризується регіональними відмінностями у забезпеченні населення лікувальними установами. Південні райони області на порядок краще забезпечені закладами охорони здоров’я ніж північні.
2. Найбільші міжрайонні відмінності у функціонуванні закладів охорони здоров'я стосуються територіальної доступності медичних установ. Полярні показники зони обслуговування лікарняних закладів мають Дубенський та Здолбунівський райони - 1200 та 219 км² відповідно.

3. Встановлено досить тісну кореляційну залежність між показниками кількості медичних закладів та окремими медико-демографічними характеристиками (поширення хвороб, загальна захворюваність, смертність), що вказує на залежність стану здоров’я населення Рівненської області від рівня розвитку їі медичного обслуговування.

Серед векторів майбутніх досліджень найактуальнішим $\epsilon$ наукове обгрунтування оптимальної моделі системи охорони здоров'я Рівненської області, яка забезпечуватиме адекватне співвідношення між потребами населення у медичних послугах i ресурсним потенціалом цієї сфери. Створення такої моделі передбачає удосконалення ㄲï територіальної організації, наближення медичної допомоги до споживача, удосконалення функціонально-організаційної моделі на принципах сімейної медицини.

\section{References:}

1. Baranovs'kij M. O. Socìal'na ìnfrastruktura depresivnih agrarnih teritorìj: regìonal'nì vìdmìnnostì, metodi vivčennâ, osoblivostì rozvitku (na prikladì Polìs'kogo ekonomǐčnogo rajonu) [Social infrastructure of depressive agrarian territories: regional differences, study methods, and peculiarities of development (the case of Polesian economic region)]. Visnik Ternopil's'kogo nacional'nogo ekonomičnogo unìversitetu [Bulletin of Ternopil National Economic University], 2007, Vol. 2, 2007, pp. 124-134. (In Ukrainian).

2. Kornus O. G., Kornus A. O., Šiŝuk V.D. Teritorial'no-nozologǐcna struktura zahvorûvanostìnaselennâ Sums'koï oblastì [Territorial nosology structure of morbidity in Sumy Region]. Sumy, 2015, 172 p. (In Ukrainian).

3. Lehan V. M., Slabkij G.O., Ševčenko M.V. Strategiâ rozvitku sistemi ohoroni zdorov'â: ukraïns'kij vimìr [Healthcare system development strategy: Ukrainian dimension]. Kyiv, 2009, 353 p. (In Ukrainian).

4. Official site of the Ukrainian State Service of Statistics. Access mode: http://www.ukrstat.gov.ua.

5. Official site of the Main Department of Statistics in Rivne Region. Access mode: http://www.rv.ukrstat.gov. ua.

\section{ПОДЯКА}

Доктору географічних наук, професору Барановському Миколі Олександровичу за цінні поради під час написання статті. 